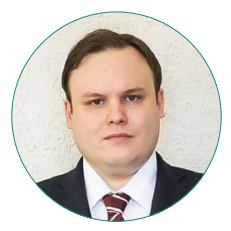

Д.Б. Литвинцев

\title{
ЗО ЛЕТ ПРИВАТИЗАЦИИ ЖИЛЬЯ В РОССИИ: УДАЛОСЬ ЛИ ВОСПИТАТЬ ОТВЕТСТВЕННЫХ СОБСТВЕННИКОВ?
}

\section{Правильная ссылка на статью:}

Литвинцев Д.Б. 30 лет приватизации жилья в России: удалось ли воспитать ответственных собственников? // Мониторинг общественного мнения: экономические и социальные перемены. 2021. № 2. С. 186-212. https://doi.org/10.14515/monitoring.2021.2.1273.

\section{For citation:}

Litvintsev D. B. (2021) 30 Years of Housing Privatization in Russia: Have We Managed to Bring Up Responsible Owners?. Monitoring of Public Opinion: Economic and Social Changes. No. 2. P. 186-212. https://doi.org/10.14515/monitoring.2021.2.1273. (In Russ.) 
30 ЛЕТ ПРИВАТИЗАЦИИ ЖИЛЬЯ В РОССИИ: УДАЛОСЬ ЛИ ВОСПИТАТЬ ОТВЕТСТВЕННЫХ СОБСТВЕННИКОВ?

ЛИТВИНЦЕВ Денис Борисович - соискатель ученой степени кандидата социологических наук, Новосибирский государственный технический университет, Новосибирск, Россия E-MAIL:denlitv@inbox.ru https://orcid.org/0000-0002-0358-3681

Аннотация. Приватизация жилья в России почти 30 лет назад привела к появлению нового социального класса - собственников общего имущества в многоквартирных домах. Посредством участия в общих собраниях собственники управляют этим имуществом и принимают решения о его использовании. Статья отражает результаты социологического исследования итогов реализации одного из ключевых направлений “Стратегии развития жилищно-коммунального хозяйства в Российской Федерации на период до 2020 года" - формирования активных и ответственных собственников помещений в многоквартирных домах. В результате интернет-опроса 675 жителей Новосибирска, привлеченных посредством методики локального ривер-сэмплинга, делается вывод о том, что реформа жилищнокоммунального хозяйства в России состоялась не в полной мере. Более трети собственников никогда не принимают участие в общих собраниях потому, что не видят в этом никакого смысла и/или не находят на это времени. Более чем в половине многоквартирных домов не избран совет дома. Уровень жилищной грамотности собственников достаточно низкий: они до конца не понимают свои права и обязанно-
30 YEARS OF HOUSING PRIVATIZATION IN RUSSIA: HAVE WE MANAGED TO BRING UP RESPONSIBLE OWNERS?

Denis B. LITVINTSEV ${ }^{1}$ —Cand. Sci. (Soc.) degree seeking applicant

E-MAIL:denlitv@inbox.ru

https://orcid.org/0000-0002-0358-3681

\footnotetext{
1 Novosibirsk State Technical University,

Novosibirsk, Russia
}

Abstract. The privatization of housing in Russia started almost 30 years ago and led to the emergence of a new social class - the owners of common property in apartment buildings who, through participation in general meetings, manage this property and make decisions about its use. The paper presents the findings revealed within a sociological survey concerning the outcomes of one of the main directions of the "Strategy for the Development of Housing and Communal Services in the Russian Federation for the Period until 2020", which is the formation of active and responsible owners of premises in apartment buildings. The survey was conducted online, and its sample consisted of 675 residents of Novosibirsk, recruited with the local river sampling technique. Basing on its results, the author concludes that the reform of housing and communal services in Russia has not yet been fully implemented. More than a third of owners never take part in general meetings because they do not see any reason in this process and/or do not allocate time for it. More than half of the apartment buildings have not elected a house council. The level of housing literacy is quite low among owners: they do not fully understand their rights and obligations, and do not realise common 
сти, не осознают общее имущество как объект права и т.п. В ходе корреляционного анализа было установлено, что такие факторы, как возраст, образование, знание норм жилищного законодательства, знакомство с соседями и участие в общественных мероприятиях, желание иметь квартиру в конкретном доме и наличие избранного совета дома, влияют на степень активности собственников в управлении многоквартирным домом посредством участия в общих собраниях. Сформирован профиль ответственного собственника и образ многоквартирного дома, где такие собственники проживают. Предложены рекомендации по совершенствованию жилищной политики и жилищного законодательства Российской Федерации с целью повышения жилищной грамотности.

Ключевые слова: жилищная социология, жилищное право, жилищно-коммунальное хозяйство, многоквартирный дом, собственник помещения, общее собрание, общее имущество property as a subject of law. The correlation analysis shows that factors such as age, education, knowledge of housing legislation, acquaintance with neighbors and participation in public events, as well as the desire to have an apartment in a particular building and the presence of an elected building council affect the degree of owners' activity in managing an apartment building through participation in general meetings. The study allows composing the profile of a responsible owner and the image of an apartment building where such owners live. In conclusion, the author formulates the recommendations for the housing policy and housing legislation of the Russian Federation aimed at increasing housing literacy.

Keywords: sociology of housing, housing and utilities, housing literacy, apartment building, owner of premises, general meeting, common property

\section{Введение}

Прошло уже почти 30 лет со старта приватизации жилья и начала реформирования всей отрасли жилищно-коммунального хозяйства (ЖКХ) в России. К середине 2019 г. было приватизировано 82\% всех жилых помещений, подлежащих передаче в частную собственность ${ }^{1}$. Большая часть россиян стали владельцами на праве общей долевой собственности общего имущества в своих многоквартирных домах (МКД), а именно: чердаков, подвалов, лифтов и квартирных холлов, земельных участков, на которых расположены МКД, и т. п. Собственники как жилых, так и нежилых помещений владеют, пользуются и в установленных российским законодательством пределах распоряжаются общим имуществом в МКД.

Параллельно с ростом числа приватизированных жилых помещений в России с начала 2000-х годов до 2015 г. отмечался ежегодный рост темпов ввода в эксплуатацию жилья. Несмотря на определенный спад, который начался в 2016 г.,

\footnotetext{
1 Основные показатели жилищных условий населения // Федеральная служба государственной статистики Российской Федерации. URL: https://rosstat.gov.ru/folder/13706 (дата обращения 23.03.2021).
} 
в 2019 г. было введено в действие 80,3 млн м² жилья ${ }^{2}$, что в 2,65 раза превышает аналогичный показатель 2000 г. (30,3 млн м²).

Однако не темпы приватизации жилья и ввода в эксплуатацию новых жилых помещений подчеркивают актуальность социологических исследований в жилищной сфере, а те проблемы, с которыми сталкиваются участники рынка услуг ЖКХ, а именно собственники помещений в МКД и управляющие организации, товарищества собственников жилья (ТСЖ, ТСН), жилищные и жилищно-строительные кооперативы (ЖСК).

В 2005 г. по результатам общероссийского социологического исследования, проведенного в 11 территориально-экономических районах страны, была выявлена положительная динамика в отношении россиян к существующей в стране частной собственности. Однако большинство граждан, говоря о частной собственности, имели в виду непосредственно свою квартиру [Горшков и др., 2005]. В 2018 г. в результате совместного исследования Московского центра Карнеги и Аналитического центра Юрия Левады был также сделан вывод о том, что «частная собственность в представлении граждан - это, прежде всего, квартира" [Волков, Колесников, 2018: 1]. 93\% опрошенных посчитали, что квартира - это образец частной собственности, при этом упуская тот факт, что квартира как обособленная жилая ячейка не может технически функционировать автономно от архитектуры и коммуникаций МКД, а значит, от общего имущества.

Подобное понимание частной собственности на жилище непосредственно отражается на участии россиян в реформе ЖКХ в России, что подтверждает ежегодное социологическое исследование ВЦИОМ "Осведомленность россиян о реформе ЖКХ". Согласно его результатам, подавляющее большинство заинтересовано в установке в квартире приборов учета воды, энергосберегающих ламп и электрооборудования. В меньшей степени собственники принимают участие в благоустройстве территории своего дома и непосредственно в общих собраниях (далее - ОС) [Осведомленность россиян..., 2019]. Н. В. Абрамова в результате исследования, проведенного в 2020 г., также пришла к выводу, что “укоренившееся представление многих жителей о том, что их ответственность за жилье прекращается за дверью квартиры, а все остальные проблемы должно решать государство", препятствует солидаризации активистов с остальными жильцами МКД [Абрамова, 2020: 79].

Социологическое исследование, проведенное А. В. Ермишиной и Л. В. Клименко в 2009 г. в городах Ростовской области (Ростов-на-Дону и Азов), показало, что существовавший на тот момент уровень зрелости собственников жилых помещений в МКД был недостаточным для успешного реформирования системы ЖКХ: "для большинства собственников жилья в МКД характерны пассивность, неорганизованность, склонность к государственному и муниципальному иждивенчеству, отсутствие навыков принятия коллективных решений, недоверие к соседям и власти" [Ермишина, Клименко, 2010: 132]. Как отмечают Н. П. Рыжова и Т. Н. Журавская, “для производства новых граждан, соответствующих рыночной идеологии, долж-

\footnotetext{
2 Ввод в действие жилых домов в городской и сельской местности в Российской Федерации // Федеральная служба государственной статистики Российской Федерации. URL: https://rosstat.gov.ru/folder/14458 (дата обращения 16.04.2021).
} 
ны быть изменены не только законодательство, ментальность, рациональность, техники и коррупционные отношения, но и материальная инфраструктура, что представляется совершенной утопией" [Рыжова, Журавская, 2019: 62].

Многочисленные эксперты в сфере управления МКД в России также отмечают, что, во-первых, собственники считают проведение ОС обременительной обязанностью, не понимают их необходимости и не считают это важным. Во-вторых, основная масса жителей МКД разрознена, соседи по одной лестничной клетке могут быть не знакомы друг с другом, хотя именно добрососедские отношения являются одной из основ эффективного управления МКД. В-третьих, собственники помещений в МКД плохо знакомы с нормами жилищного законодательства, не понимают свои права и не принимают возложенные на них обязанности [Litvintsev, Osmuk, Litvintseva, 2020].

Ввиду того, что коллективное управление многоквартирными домами (кондоминиумами) посредством ОС имеет место не только в России, зарубежные исследователи также приходят к выводу, что зачастую сами собственники становятся препятствием в принятии тех или иных решений. Например, в Японии именно сложность коллективного процесса принятия решения собственниками стоит на пути эффективной реконструкции старых многоквартирных домов [Yamazaki, Sadayuki, 2017]. В Китае из-за проблемы безбилетника ${ }^{3}$ жители кондоминиумов неохотно вступают в комитеты по управлению и вносят свой вклад в управление местными благами [Chu, Chang, Sing, 2013].

Реформирование жилищного законодательства происходит по всему миру, и в этом процессе именно законодатели играют важную роль в определении общественных ценностей и целей, которыми должны руководствоваться собственники при осуществлении коллективных действий по управлению многоквартирными домами. При этом необходимо учитывать соответствие коллективных действий, предусмотренных реформой, с преобладающими культурными ориентациями, ценностями и убеждениями, которые предопределяют повседневное взаимодействие индивидов в каждом конкретном обществе [Lehavi, 2005]. К аналогичным выводам в своем исследовании в 2014 г. пришли Е.И. Борисова, А.А Пересецкий и Л.И. Полищук: массовое внедрение коллективного управления многоквартирными домами без соответствия культурным и институциональным условиям является контрпродуктивно [Borisova, Polishchuk, Peresetsky, 2014].

Исследуя многоквартирные дома в Индии, Д. Патель указывает, что в густонаселенных кондоминиумах возрастает сложность социальных отношений из-за укоренившихся культурных иерархий [Patel, 2017]. Д. С. Харрис подчеркивает, что кондоминиум способствует вертикальному разделению земли и позволяет значительно увеличить плотность частных интересов [Harris, 2011], что в целом характерно не только для США. Кондоминиумы стали важной формой владения жильем как для самих жильцов, так и для тех, кто сдает свои квартиры в аренду (нерезидентов) как в Канаде [Preston, Murdie, Northrup, 1993], так и в России.

Роль ОС как коллективного действия собственников помещений в МКД в России сложно переоценить - это орган управления МКД. Собрания проводятся в целях

\footnotetext{
3 Проблема безбилетника - уклонение отдельных жителей от исполнения своих обязанностей по оплате за общественное благо. В случае кондоминиумов - уклонение от оплаты за его содержание и ремонт.
} 
управления МКД путем обсуждения вопросов повестки дня и принятия решений по вопросам, поставленным на голосовании, в пределах компетенции ОС: выбор способа управления, текущего и капитального ремонта, использования и сдачи в аренду общего имущества и т. п. Вопросы, отнесенные к компетенции ОС, строго регламентированы Жилищным Кодексом (ЖК) Российской Федерации.

Жилищным законодательством РФ предусмотрено три формы проведения ОС в МКД: очное голосование путем совместного присутствия, заочное голосование опросным путем и очно-заочное голосование. Собственники помещений в МКД обязаны ежегодно проводить годовое ОС, что устанавливает его периодичность. Игнорирование собственниками обязанности по проведению ОС неизбежно сказывается на надлежащем содержании общего имущества в МКД, а также может привести к нарушениям, в том числе со стороны управляющих организаций, ТСЖ и ЖСК требований законодательства РФ в области обеспечения санитарноэпидемиологического благополучия населения, о техническом регулировании, пожарной безопасности, защите прав потребителей и т. п. Кроме того, для управляющей организации без проведения ОС невозможно в одностороннем порядке определить размер платы за содержание общего имущества в МКД-нередки случаи, когда собственники не повышают размер платы в течение нескольких лет, несмотря на рост инфляции, удорожание материалов, работ и услуг подрядчиков, необходимость индексации зарплат работников управляющих организаций и т. п.

О. С. Сидорова в ходе анализа результатов количественного источника и лейтмотивных интервью, проведенных в 2013 г. в Новосибирске (Академгородок), сделала предположение о факторах, влияющих на проявление жителями социальной активности в управлении МКД. Такими факторами стали социальнодемографические (пол, возраст) и социально-экономические (образование, вид занятости) характеристики жителей, их включенность в соседские отношения (в том числе продолжительность проживания в доме) и характеристики самого МКД [Сидорова, 2013].

\section{Дизайн исследования}

26 января 2016 г. распоряжением Правительства РФ № 80-р была утверждена "Стратегия развития жилищно-коммунального хозяйства в Российской Федерации на период до 2020 года", одним из ключевых направлений которой являлось формирование активности и ответственности собственников помещений в МКД 4 . Актуальность исследования, таким образом, обосновывается необходимостью подвести своего рода итоги реализации данной Стратегии в части формирования активных и ответственных собственников помещений в МКД посредством проведения социологического исследования.

Цель исследования - проанализировать степень активности собственников помещений в МКД, выявить факторы, влияющие на активность и частоту участия в ОС, и сформировать профиль ответственного собственника, а также образ МКД, в котором такие собственники проживают.

\footnotetext{
4 Стратегия развития жилищно-коммунального хозяйства в Российской Федерации на период до 2020 года. Распоряжение Правительства РФ от 26.01.2016 № 80-р (ред. от 18.10.2018). URL: http://www.consultant.ru/ document/cons_doc_LAW_192971/(дата обращения: 08.04.2021).
} 
Метод исследования - интернет-опрос посредством анкетирования. Анкета была разработана на платформе Google Forms и доступна по ссылке для любого устройства (персональный компьютер, ноутбук, планшет, смартфон), что позволяло респондентам отвечать на вопросы в любое время, находясь как у себя дома, так и на работе, в дороге и т. п. С целью рекрутинга респондентов применялась методика локального ривер-сэмплинга - приглашение и ссылка на опрос распространялись посредством мессенджеров (WhatsApp и др.), крупных новосибирских форумов и социальных сетей (преимущественно новосибирские паблики «ВКонтакте»). Опрос проходил с ноября 2019 г. по февраль 2020 г.

Экспорт данных из Google Forms был осуществлен через контейнер XLSX (Microsoft Office Excel). Анализ данных произведен посредством программного обеспечения IBM SPSS Statistics версии 23. В ходе анализа применялся непараметрический метод Хи-квадрат (критерий согласия Пирсона). Гипотеза принималась в случае значимости критерия ( $p<0,05)$ с учетом величины эффекта (V Kрамера).

Целевая аудитория исследования: население Новосибирска в возрасте от 18 лет и старше. В исследовании могли принять участие только совершеннолетние собственники помещений в МКД, расположенных в Новосибирске. Это связано с тем, что правом голосования на ОС в МКД по вопросам, поставленным на голосование, обладают собственники помещений в данном доме или их законные представители. Выборочная совокупность исследования составила 675 человек из десяти районов Новосибирска. В исследовании приняли участие мужчины и женщины трех возрастных групп, имеющие разный род деятельности и материальное положение (см. Приложение).

В связи с тем, что по данным Федеральной службы государственной статистики Российской Федерации в 2018 г. 74,5\% домохозяйств в Новосибирской области имели широкополосный доступ в интернет (в Новосибирске, соответственно, этот показатель выше), активные интернет-пользователи в Новосибирской области составляли 79,3\% [Информационное общество в Российской Федерации, 2019], и с учетом примененного метода рекрутинга респондентов выборочную совокупность можно считать достаточно репрезентативной. Данный подход основывается на позиции специалистов НИУ ВШЭ5

\section{Активность собственников и фактор соседства}

Почти треть опрошенных (29,2\%)- ответственные собственники, принимающие участие в каждом собрании (“активные» [Ермишина, Клименко, 2010], "действующие лица» [Сидорова, 2013], “активисты” [Абрамова, 2020]). Наличие активистов характерно для каждого МКД, тем не менее данное количество активно действующих собственников в условиях существующих формальных институтов управления МКД расценивается как недостаточное - в соответствии с нормами действующего жилищного законодательства ОС в России правомочно, если в нем приняло участие более половины всех собственников помещений в МКД (или больше по отдельным вопросам).

\footnotetext{
5 Сотрудниками ИГМУ НИУ ВШЭ разработана и внедрена система проведения социологических исследований с привлечением респондентов в сети интернет по принципу поточной выборки (river sampling). URL: http://gos.hse. ru/news/417/ (дата обращения 14.04.2021).
} 
$25,5 \%$ собственников принимают участие в ОС от случая к случаю, а 11,3\%крайне редко, что, очевидно, зависит от множества факторов. Более трети опрошенных собственников (34,1\%) никогда не принимают участия в ОС. Таким образом, группе активных жильцов дома противопоставляется чуть более многочисленная группа пассивных жильцов (“инертные» [Ермишина, Клименко, 2010], "одиночки" [Сидорова, 2013], "обыватели" [Абрамова, 2020]), на которую не приходится рассчитывать в ходе принятия решений по тем или иным вопросам на ОС. Складывающаяся ситуация вынуждает активных собственников не просто принимать участие в ОС, но и агитировать тех, кто участвует нерегулярно ("соседи" [Сидорова, 2013]).

Большая часть собственников (51,3\%), не регулярно участвующих в ОС, попросту не находят времени для участия, примерно четверть $(22,3 \%)$ не видят в ОС никакого смысла. Подобное свидетельствует о том, что большинство собственников, по всей видимости, считают, что "и без них все решат" (что, кстати, характерно и для голосований на различных выборах в РФ), недооценивая, не понимая или не принимая свою роль в управлении МКД.

В то же время 32\% опрошенных не знают, где и когда проводятся ОС, а 20,2\% убеждены, что в их доме ОС не проводятся вообще. Таким образом, проявляются проблемы (в том числе и преднамеренные) процесса информирования участников ОС. Складывающаяся ситуация способствует фальсификации протоколов ОС - подобные случаи становятся нередким сюжетом в российских СМИ.

Наличие конфликта с другими участниками ОС $(4,1 \%)$ и проживание в другом городе (2,9\%) не являются распространенной причиной игнорирования ОС. Этому, очевидно, способствует возможность проведения ОС как в заочной форме, так и с помощью информационных систем - например, ГИС ЖКХ. Таким образом, процесс участия в ОС постепенно приобретает свойства сетевого взаимодействия.

Всего 10,4\% собственников принимают участие в очных собраниях, что неудивительно, так как очные собрания давно продемонстрировали свою неэффективность - невозможность набора необходимого кворума и необходимость проведения повторного собрания, но уже в форме заочного голосования. В связи с этим в 2015 г. была утверждена новая форма очно-заочного голосования с целью упростить процедуру ОС. При этом 34,7 \% собственников принимают участие как на очном, так и на заочном этапе голосования, 20,9\% - только на заочном.

Подавляющее большинство собственников ни разу не воспользовались своим правом стать инициатором ОС $(85,8 \%)$ и не выступали в роли председателя или секретаря ОС (89\%). Менее $20 \%$ опрошенных входят в какое-либо объединение собственников помещений в МКД (совет дома, инициативная группа и т. п.). Сложившаяся ситуация свидетельствует о том, что большинство собственников не проявляют инициативы, не хотят принимать участие в работе совета дома и (или) комиссий и не готовы участвовать в организации и проведении ОС, оформлении документов по результатам ОС и т. п. Большинство собственников - это пассивные участники ОС, готовые просто голосовать за решения по вопросам повестки. К схожим выводам приходит и Н. В. Абрамова: «многие жители готовы отдать заботы о доме более активным и компетентным соседям, сведя свое участие к голосованию по принципиальным вопросам" [Абрамова, 2020: 78]. 
Меньше половины собственников участвуют в каких-либо общественных мероприятиях, тем не менее больша́я часть (42,1\%) участвует в субботниках и (или) месячниках. Сохранение подобных советских традиций свидетельствует о наличии в МКД не просто групп активных собственников, а непосредственно тех, кто напрямую готов добровольно участвовать в жизни и эксплуатации своего дома. Чуть менее активно собственники принимают участие в дворовых праздниках (36,4\%). Вероятно, это связано как со временем проведения подобных мероприятий, так и с необходимостью дополнительного финансирования - оплаты участия музыкальных групп, детских подарков и угощений и т. п.

В благоустройстве придомовой территории принимают участие 30,1\%. Данный показатель на 7,1\% выше, чем по данным ежегодного общероссийского исследования ВЦИОМ [Осведомленность россиян..., 2019], что может быть связано с развитостью в Новосибирске такой формы самоуправления, как территориальные общественные объединения, члены которых регулярно организуют и проводят различного рода мероприятия по всему городу. Общественным жилищным контролем занимаются всего 1,4\% собственников, при этом 29,4\% занимаются разной общественной деятельностью, по всей видимости, не связанной с управлением МКД и обслуживанием общего имущества.

Большинство собственников, участвующих в общественных мероприятиях, принимают участие в каждом собрании или от случая к случаю, в то время как пассивные собственники чаще не участвуют в ОС вообще или участвуют редко (см. рис. 1). Можно говорить о том, что большинство активных собственников активно во всем - от участия в ОС до работ по благоустройству придомовой территории, организации праздников и т. п.

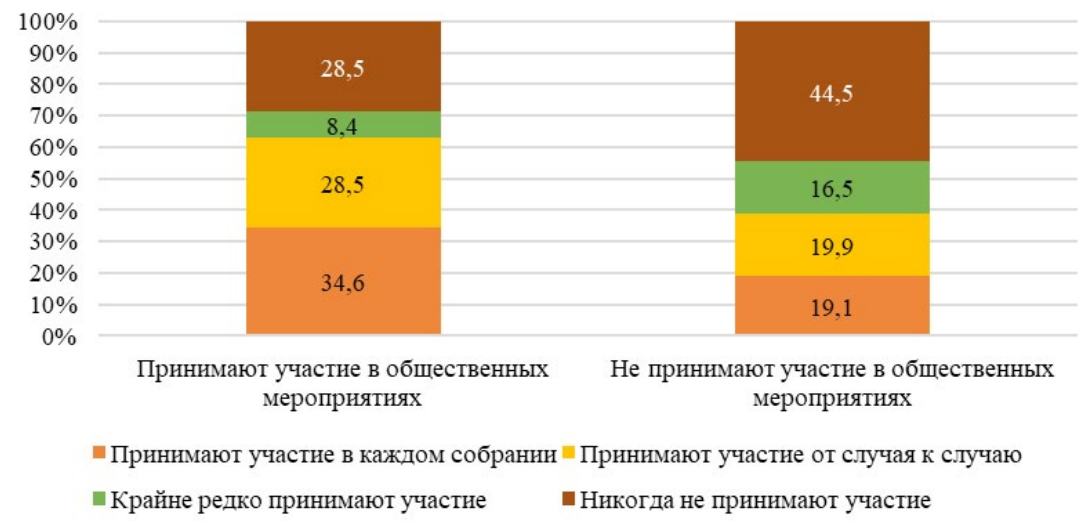

Рис. 1. Дифференциация участия собственников в ОС по участию в общественных мероприятиях (\%)

Всего 13,2 \% собственников хорошо знают большинство жителей своего дома, при этом почти пятая часть (19\%) едва знакомы с соседями по лестничной площадке. Гипотеза о влиянии соседства (выдвинутая в том числе О.С. Сидоровой [Сидорова, 2013]) на активность собственников нашла свое подтверждение. Чем выше уровень соседства, чем лучше соседи знают друг друга, тем активнее 
и чаще они принимают участие в ОС. Более половины респондентов, которые едва знакомы с соседями по лестничной клетке, никогда не принимают участие в ОС. В то же время собственники, хорошо знающие многих жителей своего МКД, в большинстве своем принимают участие в каждом собрании (см. рис. 2).

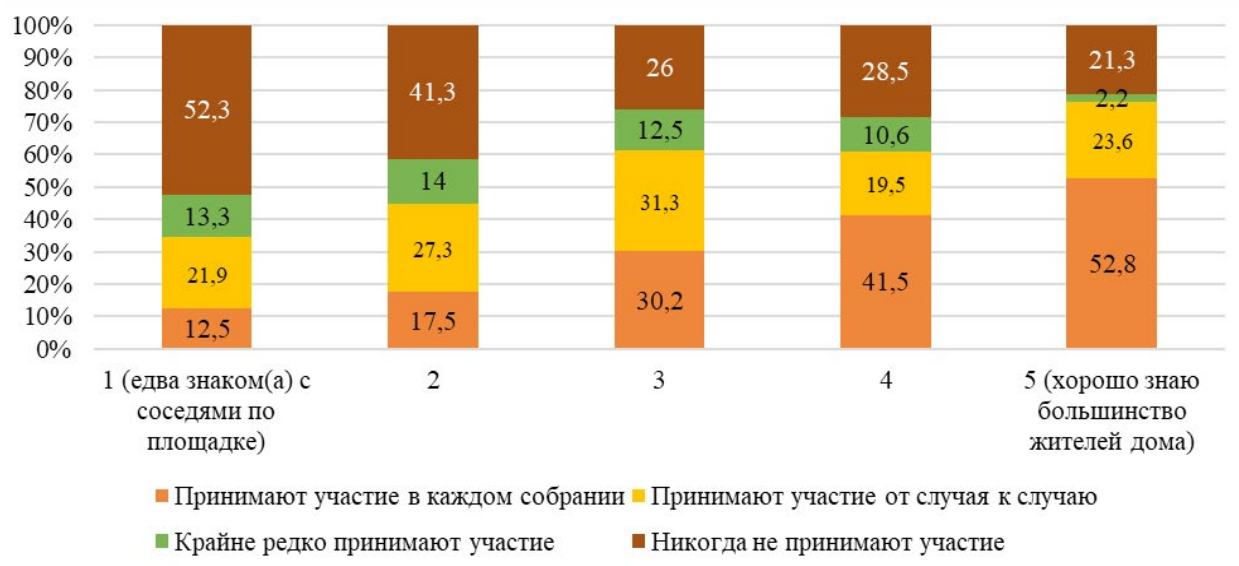

Рис. 2. Дифференциация участия собственников в ОС по степени знакомства с соседями (\%)

В данном случае можно провести параллель с высотным строительством, которое активно развивается в РФ в последние годы ${ }^{6}$. Плотность заселения МКД, на которую влияет количество этажей, подъездов и квартир, вероятно, влияет на степень соседских отношений: чем больше МКД, тем люди хуже знают друг друга [Litvintsev, Osmuk, Litvintseva, 2020]. В ходе настоящего исследования был установлен факт, что с ростом количества квартир в МКД количество хорошо знающих друг друга жителей уменьшается. Это подтверждает гипотезу о влиянии размеров МКД на активность собственников и их ответственное отношение к общему имуществу.

Целесообразно отметить, что в ходе анализа протоколов ОС собственников помещений МКД в Новосибирске, проведенного в 2020 г., были также выявлены особенности и тенденции организации ОС в двух разных группах МКД по числу Данбара: мало-, средне- и многоэтажных (до 150 квартир) и высотных (более 150 квартир) [Литвинцев, 2020].

Таким образом, степень активности собственников проявляется как в участии в ОС, так и в общественных мероприятиях и членстве в различных объединениях. Жители в разной степени знакомы со своими соседями. Участие собственников в общественных мероприятиях и хорошее знакомство соседей друг с другом влияют на их активность и ответственное отношение к общему имуществу.

\section{Социально-демографические и экономические факторы}

В ходе исследования было выявлено влияние отдельных социально-демографических и экономических характеристик собственников на их активность.

\footnotetext{
${ }^{6}$ Ввод общей площади жилых домов по этажности в Российской Федерации // Федеральная служба государственной статистики Российской Федерации. URL: https://rosstat.gov.ru/folder/14458 (дата обращения 21.03.2021).
} 
Так, если мужчины и женщины в равной степени принимают или не принимают участие в ОС, то респонденты среднего и старшего возраста активнее и чаще принимают участие в ОС, чем молодые люди в возрасте от 18 до 35 лет (см. рис. 3). Корреляция возраста с активностью участия собственников в ОС также подчеркивалась в других исследованиях [Ермишина, Клименко, 2010; Сидорова, 2013]. Это свидетельствует о том, что формирование чувства ответственности не только за свою квартиру как непосредственное жилище, но и за МКД, в котором она расположена, требует определенного жизненного опыта. С другой стороны, может сказываться фактор поколений.

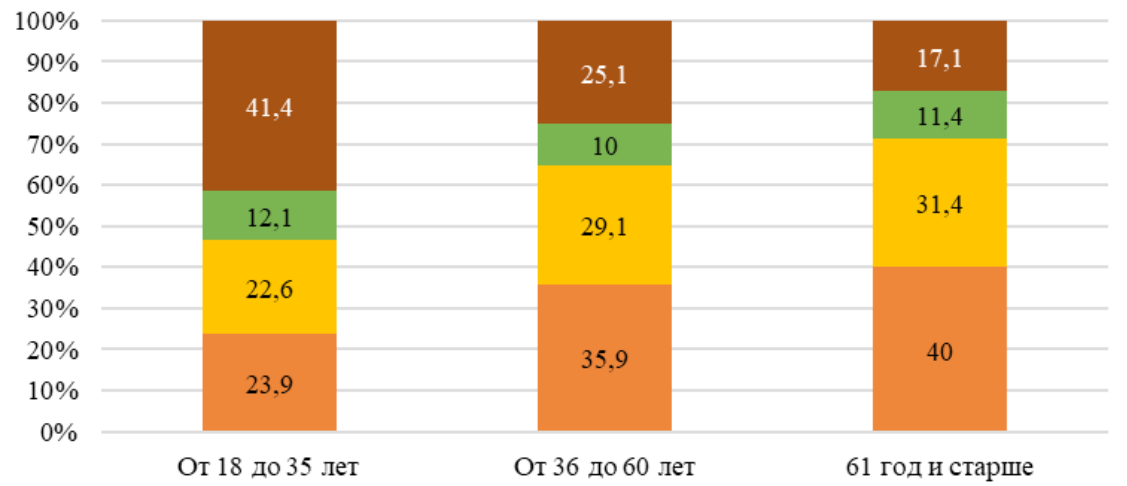

Прннимают участие в каждом собранни - Прннимают участие от случая к случаю

- Крайне редко прннимают участне - Ннкогда не прнннмают участне

Рис. З. Дифференциация участия собственников в ОС по возрасту (\%)

При этом род деятельности не влияет на активность собственников: учащиеся, работающие и домохозяйки в равной степени принимают и не принимают участие в ОС. Этот результат отличается от уже имеющихся [Ермишина, Клименко, 2010; Сидорова, 2013], что в данном случае скорее говорит не об особенностях жителей Новосибирска, а об изменении ситуации в России в целом - усложнении жизненных процессов, среди которых вопросы управления МКД отодвигаются на задний план. Также не влияет на активность собственников и материальное положение.

Еще один фактор, влияющий на активность собственников, - образование, что отмечали и другие исследователи [Ермишина, Клименко, 2010; Сидорова, 2013]. Треть респондентов с высшим образованием (в том числе имеющие два и более) принимают участие в каждом ОС. При этом большинство собственников, имеющих только основное или среднее (техническое или специальное) образование, никогда не принимают участие в собраниях (см. рис. 4). В этом плане не просто жизненный опыт, а непосредственно уровень образованности респондента позволяет ему осознанно относиться к вопросам управления МКД и повышает степень его активности на ОС. Логично предположить, что образование влияет на знания собственников о нормах жилищного законодательства РФ. 


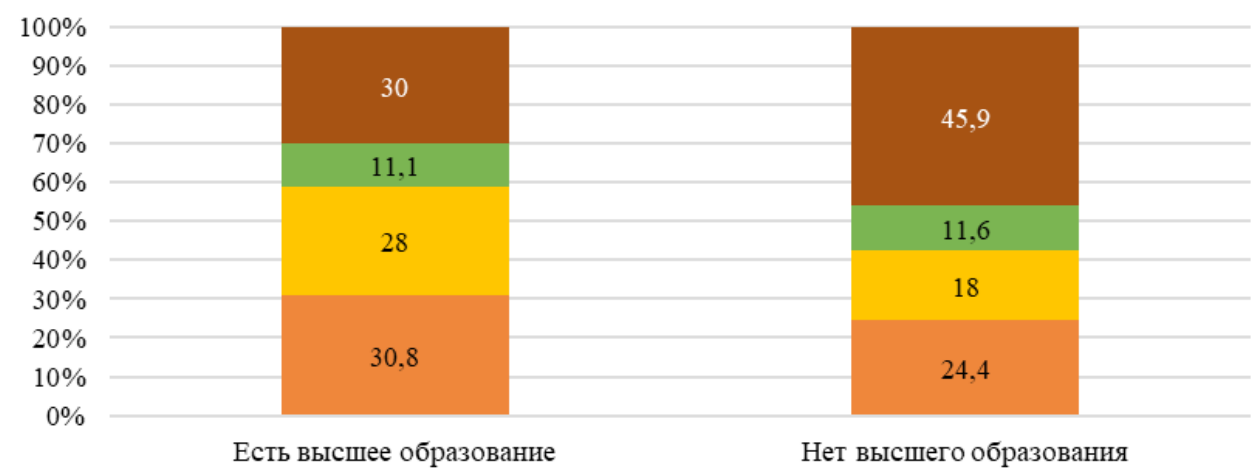

- Принимают участие в каждом собрании $"$ Принимают участие от случая к случаю

- Крайне редко приннмают участие $\quad$ Ннкогда не прннимают участие

Рис. 4. Дифференциация участия собственников в ОС по образованию (\%)

Таким образом, чем старше собственники и чем выше их уровень образования, тем ответственнее они относятся к общему имуществу в МКД, участвуя в ОС. Необходимо отметить, что аналогичные категории населения России являются и активными участниками реформы ЖКХ, согласно результатам исследования, проведенного ВЦИОМ [Осведомленность россиян..., 2019].

\section{Жилищная грамотность как фактор активности}

В ходе исследования респондентам было задано четыре вопроса о знании правовых норм, предусмотренных ЖК РФ, с целью выявления уровня жилищной грамотности собственников помещений в МКД и его влияния на активность участия в ОС.

На первый вопрос "Знаете ли Вы, что является органом управления многоквартирным домом?” только 19,8\% собственников дали корректный ответ - "Общее собрание собственников". 31,6 \% считают, что орган управления МКД - это управляющая организация, 13,2\% - правление товарищества собственников или кооператива (ТСЖ, ТСН, ЖСК и т. п.). То есть практически половина опрошенных (44,8\%) делегировали свои права и обязанности по управлению МКД организациям, выбранным в соответствии со способом управления, что свидетельствует о преобладании советского менталитета - ЖЭУ, ЖЭК и т. п. должны решать все вопросы по обслуживанию МКД самостоятельно. Меньшая часть опрошенных переложили ответственность на совет МКД $(7,6 \%)$ или его председателя (5\%). 22,7 \% опрошенных вообще затруднились дать ответ на поставленный вопрос.

Почти половина собственников, давших корректный ответ на первый вопрос, принимают участие в каждом собрании. Собственники, давшие неверный ответ или затруднившиеся с ответом, в большинстве своем никогда не принимают участие в ОС. Таким образом, знание собственниками ключевой нормы жилищного права РФ влияет на их активность в ОС (см. рис. 5). 


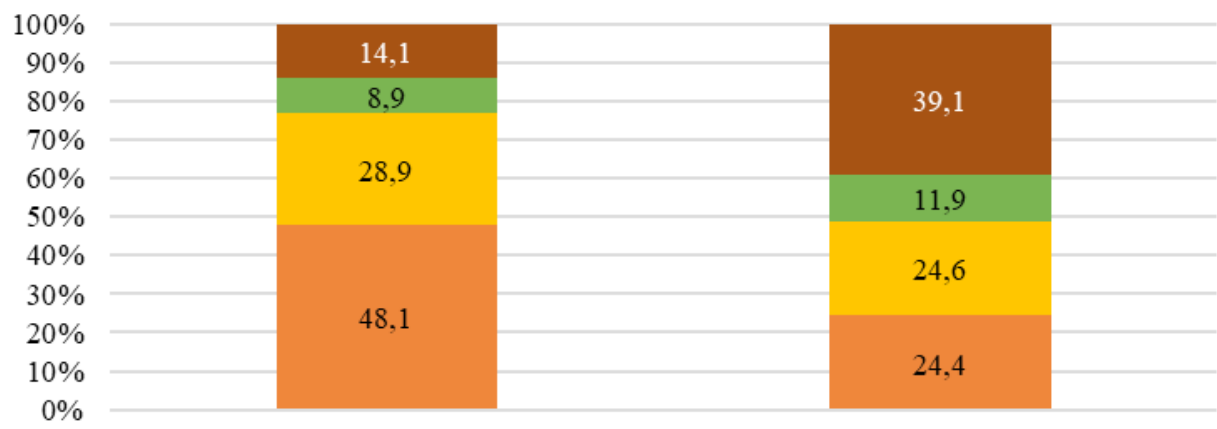

Дали верный ответ

Дали неверный ответ нли затруднились с ответом

Принимают участие в каждом собранин $₫$ Принимают участне от случая к случаю

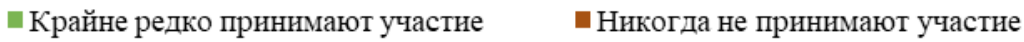

Рис. 5. Дифференциация участия собственников в ОС по знанию органа управления МКД (\%)

Важность второго вопроса «Знаете ли Вы, что входит в состав общего имущества в многоквартирном доме?" заключается не просто в знании собственниками состава общего имущества, а в понимании непосредственно объекта права. Только 29,2\% респондентов указали корректный (хоть и краткий) вариант ответа «инженерные сети, электрооборудование и конструктивные элементы дома, обслуживающие более одной квартиры". 35,9\% собственников вообще не знают, что такое общее имущество, а для $24 \%$ это все, что находится за пределами квартиры. И если в первом случае они попросту не осознают объект права, то позиция вторых вызывает некоторое опасение: именно такие собственники препятствуют в доступе обслуживающим организациям в свои квартиры для ремонта общедомовых инженерных коммуникаций, остекляют балконы, считая их частью своей квартиры, и вообще нередко занимают позицию “все, что за дверями моей квартиры, меня не касается".

Менее $6 \%$ собственников (5,8\%) наделили правами утверждать состав общего имущества управляющую организацию или правление товарищества собственников, 1,5\% - совет МКД или его председателя. Данная позиция в совокупности с аналогичными ответами на предыдущий вопрос свидетельствует о том, что существует определенная категория собственников, готовых не просто снять с себя часть прав и обязанностей, а фактически наделить сверхправами тех, кому они готовы полностью доверить все вопросы по управлению МКД. 3,7 \% собственников считают, что состав общего имущества формируется исключительно по решению ОС. Это также некорректно - решением ОС собственники вправе уменьшить размер общего имущества или включить в него новое (например, вновь установленные камеры видеонаблюдения). С другой стороны, если бы большинство собственников дали подобный ответ на поставленный вопрос, это свидетельствовало бы о об их готовности взять на себя максимум ответственности.

Более трети собственников, давших корректный ответ на второй вопрос, принимают участие в каждом собрании. Собственники, давшие неверный ответ или 
затруднившиеся с ответом, в большинстве своем никогда не принимают участие в ОС. Из этого следует, что понимание собственниками самого объекта права (общего имущества) влияет на их ответственное отношение (см. рис. 6).

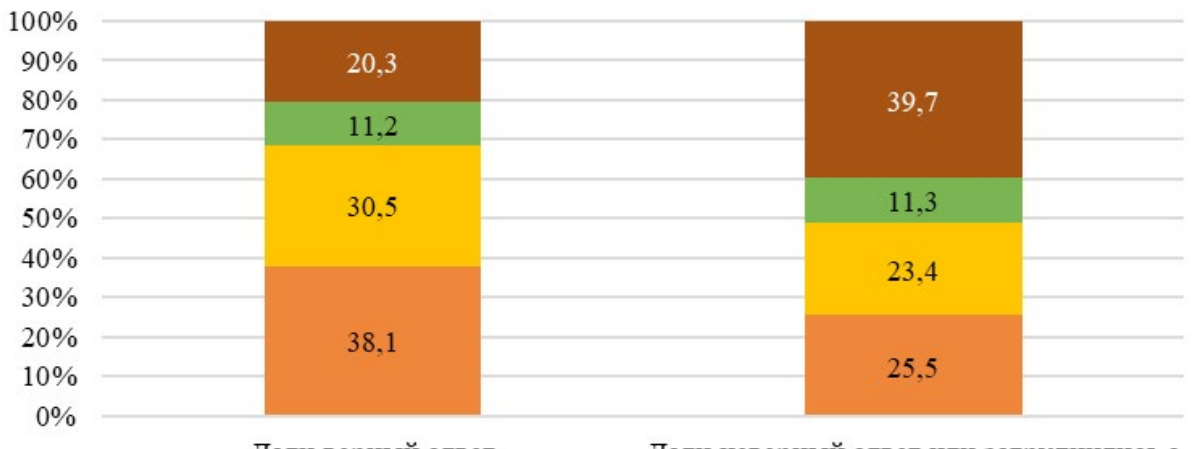

Дали верный ответ

Дали неверный ответ или затруднились с ответом

" Принимают участие в каждом собранин

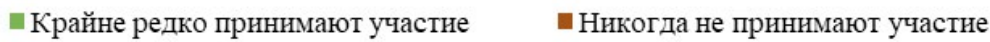

Рис. 6. Дифференциация участия собственников в ОС по знанию состава общего имущества в МКД (\%)

Ответы на третий вопрос “Знаете ли Вы, что относится к компетенции общего собрания?" дают понять, насколько широко собственники видят задачи ОС. Несмотря на то, что к компетенции ОС в МКД отнесен ограниченный перечень вопросов, об этом знают лишь 10,8\% собственников, при этом 35,9\% вообще затруднились с ответом на данный вопрос. 31,7 \% опрошенных считают, что инициатор ОС вправе выносить любые вопросы на голосование. В данном случае незнание норм жилищного законодательства сказывается на злоупотреблении собственниками правом посредством ОС - типичным примером может служить установка шлагбаума на территории, не входящей в состав общего имущества. 12,1\% респондентов считают, что вопросы, выносимые на голосование, должны согласовываться с управляющей организацией или правлением товарищества собственников, 9,5\% - советом дома или его председателем. Данная позиция подтверждает неуверенное знание собственниками норм жилищного законодательства, что и подтверждается на практике: в большинстве случаев документы для проведения ОС готовят либо советы домов, либо специалисты управляющих организаций, в структуре которых существуют целые отделы по работе с населением.

Большинство собственников, давших корректный ответ на третий вопрос, принимают участие в каждом собрании. Более трети собственников, давших неверный ответ или затруднившихся с ответом, никогда не принимают участие в ОС. Таким образом, понимание собственниками задач ОС влияет на их участие в этих собраниях (см. рис. 7). 


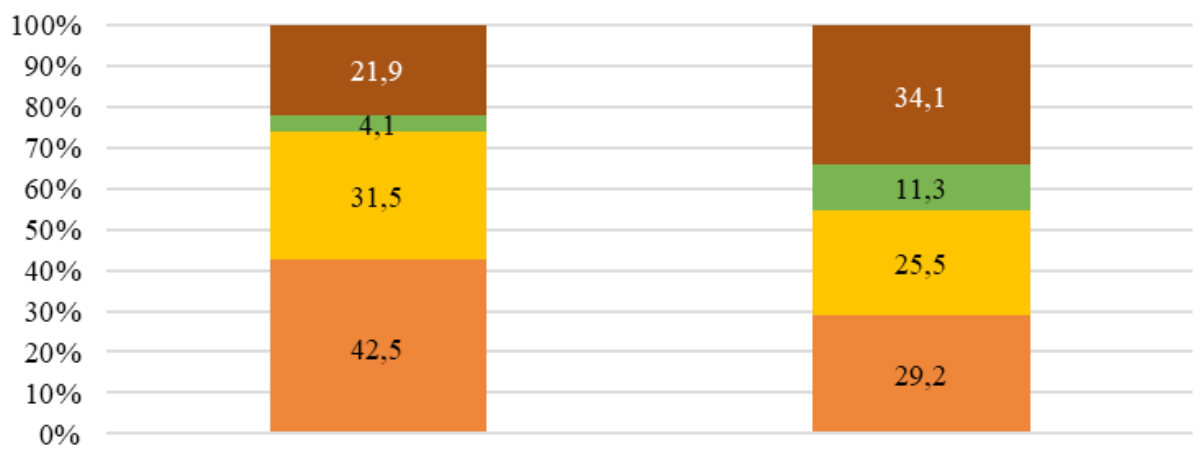

Дали верный ответ

Дали неверный ответ нли затруднились с ответом

Принимают участие в каждом собрании $₫$ Принимают участие от случая к случаю

ॠрайне редко прннимают участие घнкогда не прннимают участие

Рис. 7. Дифференциация участия собственников в ОС по знанию компетенции ОС (\%)

Ответы собственников на четвертый вопрос «Знаете ли Вы, кто может инициировать общее собрание?" свидетельствуют о понимании роли каждого участника OC. Собрание может проводиться по инициативе любого собственника помещения в МКД либо правления товарищества собственников или управляющей организации, осуществляющей управление МКД по договору управления. В отдельных случаях орган местного самоуправления также вправе инициировать ОС в МКД, однако это не играет существенной роли в рамках настоящего исследования и не было включено в корректный вариант ответа на вопрос с целью не усложнять выбор ответа респондентам.

Корректный ответ на вопрос дали 40,1\% опрошенных, что свидетельствует о неплохом знании собственниками своих прав в части инициирования ОС. В пользу данного вывода свидетельствует и то, что 9,3\% респондентов ошибочно считают, что инициировать ОС могут исключительно собственники. 16,9\% собственников, ошибочно считающих, что инициировать ОС может любое заинтересованное лицо, по всей видимости, занимают позицию “кому надо, пусть тот и инициирует". 2,7 \% респондентов переложили свои права на управляющую организацию или правление товарищества собственников, 4,3\% - на совет МКД или его председателя. $26,7 \%$ опрошенных затруднились с ответом, хотя могли бы выбрать не совсем корректный ответ “Исключительно собственник помещения", что в очередной раз свидетельствует о незнании собственниками норм жилищного законодательства и/или непринятии своих прав и обязанностей.

Большинство собственников, давших корректный ответ на четвертый вопрос, принимают участие в каждом собрании. Почти половина собственников, давших неверный ответ или затруднившихся с ответом, никогда не принимают участие в ОС. Из этого следует, что понимание собственниками своей роли в инициации ОС влияет на степень их участия в ОС (см. рис. 8). 


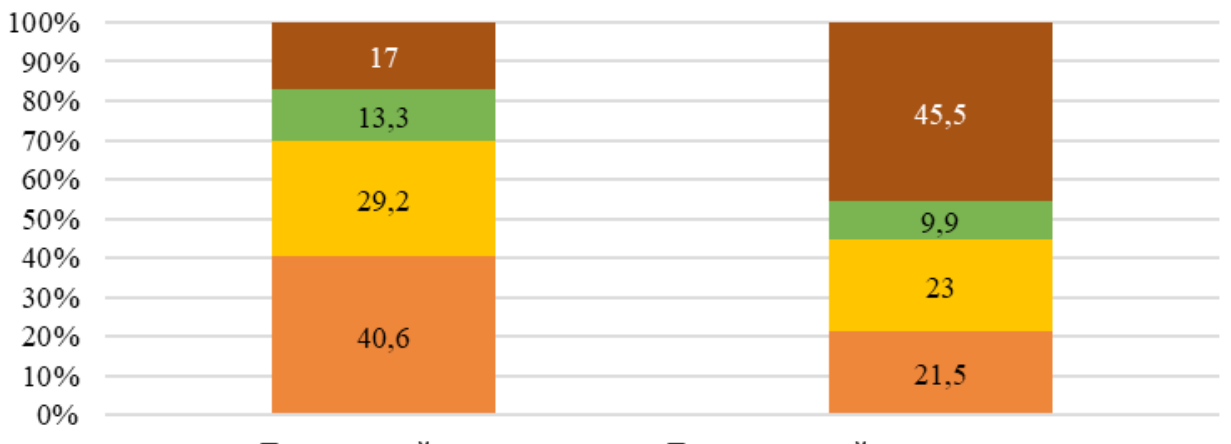

Дали верный ответ

Дали неверный ответ или затрудннлись с ответом

Принимают участие в каждом собранин ${ }^{-}$Принимают участие от случая к случаю

- Крайне редко прннимают участие — Ннкогда не прннимают участне

Рис. 8. Дифференциация участия собственников в ОС по знанию права инициировать ОС (\%)

Таким образом, уровень жилищной грамотности собственников, отражающийся в их знании норм жилищного законодательства (орган управления МКД, состав общего имущества, право инициирования ОС, компетенция ОС), влияет на их активность в ОС и ответственное отношение к общему имуществу. Чрезвычайно низкий уровень знания положений ЖК РФ свидетельствует о том, что за 30 лет приватизации не было уделено достаточно внимания именно жилищному образованию собственников помещений в МКД. В то же время за эти годы жилищное законодательство многократно усложнилось за счет многочисленных поправок в ЖК РФ, федеральных законов, постановлений Правительства РФ и т. п., нередко противоречащих друг другу и сложных для освоения среднестатистическим жителем МКД.

Как ни парадоксально, но наличие высшего образования у собственников не влияет на уровень их жилищной грамотности. Вероятно, это связано с отсутствием соответствующих предметов (дисциплин) в программах высшего образования. Исключение составляют лишь программы подготовки юристов, а также экономистов (управленцев) и инженеров для сферы ЖКХ.

\section{Управленческие факторы}

Чуть более трети собственников (33\%) поставили оценку "3" за качество обслуживания своего МКД, в то же время 38,3\% скорее удовлетворены $(27,6 \%)$ и полностью удовлетворены $(10,7 \%)$ работой своей управляющей организации либо ТСЖ. Скорее не удовлетворены качеством обслуживания МКД $19 \%$ собственников, а 9,8\% уверены, что по их дому "вообще ничего не делается". При этом по данным ВЦИОМ $60 \%$ россиян в целом удовлетворены качеством услуг ЖКХ. В данном случае необходимо отметить, что под услугами ЖКХ понимается не только техническое обслуживание жилого фонда, но и коммунальные услуги (отопление, водоснабжение, водоотведение, электроснабжение, газоснабжение 
и обращение с твердыми коммунальными отходами) ${ }^{7}$. Можно говорить о том, что если качество именно коммунальных услуг в большей степени стало удовлетворять жителей России, то качество непосредственно управления МКД и содержание общего имущества по-прежнему остается на достаточно невысоком уровне.

Казалось бы, собственники при ухудшении качества обслуживания своего МКД должны активнее принимать участие в ОС с целью корректировки перечня работ и услуг по содержанию общего имущества или вообще смены управляющей организации или способа управления, однако данная взаимосвязь в ходе исследования установлена не была - качество обслуживания МКД не влияет на активность участия собственников в ОС.

В соответствии с нормами жилищного законодательства РФ собственники помещений в МКД обязаны выбрать один из трех способов управления: непосредственное управление (допустимо в случае, если в МКД не более 30 квартир), управление ТСЖ либо ЖСК, управление управляющей организацией. 70,1\% респондентов указали, что способом управления их МКД выбрана управляющая организация. В 19,6\% случаев собственники указали способом управления товарищество собственников (ТСЖ, ТСН), в 5,3\% - жилищно-строительный (ЖСК) или иной кооператив, в 1,6\% - непосредственное управление. На момент участия в опросе способ управления МКД не был выбран для 3,4\% опрошенных.

Преобладание такого способа управления, как управляющая организация, отражает общероссийские тенденции - по данным ГИС ЖКХ подавляющее большинство МКД находятся в управлении управляющих организаций. При этом выбранный способ управления МКД не влияет на активность участия собственников в ОС. Отсутствие подобной закономерности, выявленной ранее [Ермишина, Клименко, 2010], безусловно, несколько озадачивает. ТСЖ как самоуправление МКД подразумевает высокую активность собственников. Однако в современных российских реалиях усматривается следующая ситуация: ТСЖ создавались несколько лет назад, произошла смена поколений, и небольшие группы оставшихся активистов ТСЖ столкнулись с той же проблемой, что и управляющие организации. А новые ТСЖ создаются крайне редко, о чем и свидетельствует статистика.

Почти в половине случаев (44,9\%) собственники указали, что у них избран совет МКД. Необходимо отметить, что в случае, если в МКД не создано ТСЖ либо этот дом не управляется кооперативом и при этом в доме более четырех квартир, собственники на ОС должны избрать совет МКД из числа собственников помещений в данном доме. Орган местного самоуправления обязан созвать ОС в трехмесячный срок, если в течение календарного года собственниками помещений в МКД совет не был избран.

Отсутствие избранного совета МКД (7,3\%) свидетельствует как об отсутствии инициативных жителей, так и о бездействии органов местного самоуправления. При этом 21,5\% собственников отметили, что совет дома не избран по причине наличия старшего по дому и (или) старших по подъездам, притом что в современной редакции ЖК РФ таких понятий нет (в данном случае не очевидно, отождествляют ли собственники совет МКД с домовым комитетом или выбирают старших

\footnotetext{
Россияне о качестве ЖКХ//ВЦИОМ. URL: https://wciom.ru/index.php?id=236\&uid=9786 (дата обращения: 23.03.2021).
} 
по подъездам, руководствуясь нормами уже недействующего советского законодательства). 5 \% респондентов указали просто на наличие инициативной группы. Тот факт, что 21,3\% респондентов затруднились ответить на вопрос, избран ли в их доме совет МКД, свидетельствует о недостаточной информированности собственников, как и в случае с уведомлениями о проведении ОС.

Собственники активнее принимают участие в ОС в тех МКД, где избран совет и распространена информация о его наличии (см. рис. 9). С одной стороны, подобный фактор О.С. Сидорова идентифицировала как «принуждение» [Сидорова, 2013], а с другой - именно члены советов МКД осуществляют поквартирные обходы жильцов в вечернее время и выходные дни с целью добора необходимого количество голосов на ОС, что таким образом позволяет вовлечь в голосование менее активных жителей (в том числе и тех, кому попросту некогда).

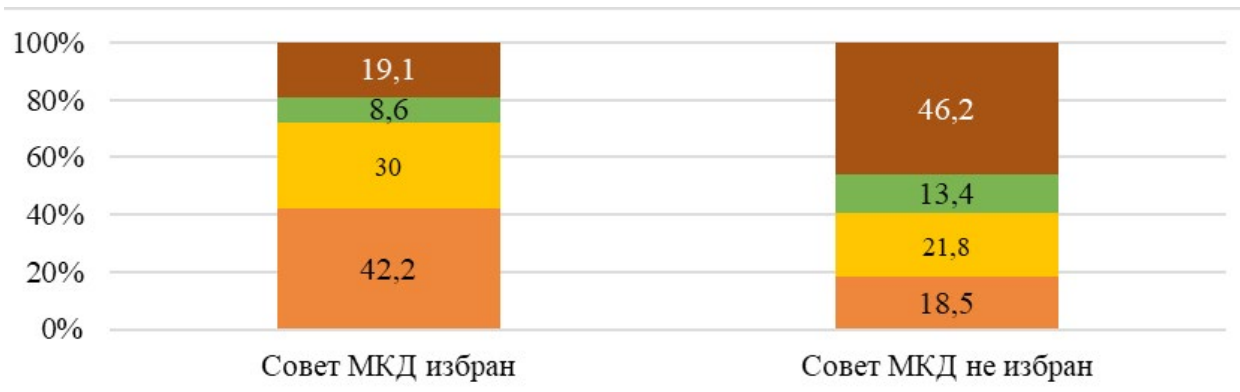

ఐринимают участие в каждом собрании $₫$ Принимают участие от случая к случаю

- Крайне редко принимают участие - Никогда не принимают участие

Рис. 9. Дифференциация участия собственников в ОС по наличию избранного совета в МКД (\%)

Таким образом, качество обслуживания и способ управления МКД не влияют на степень активности собственников. В то же время на участие собственников в ОС влияет наличие избранного совета МКД и осведомленность об этом жителей дома. А.В. Ермишина и Л.В. Клименко в 2010 г. также подчеркивали важность знакомства собственников с «активистами-управленцами" [Ермишина, Клименко, 2010].

\section{Прочие факторы}

Большинство респондентов (63,6\%) стали собственниками квартиры в МКД в период с 2011 г. по 2020 г., 24,6\% - с 2001 г. по 2010 г., а 14,8\% - в 1990-х годах По форме собственности на квартиру респонденты распределились следующим образом: 50,1\% владеют квартирой индивидуально, в то время как у 29,2\% опрошенных квартира находится в долевой собственности, а у $20,7 \%$ респондентов - в общей совместной. Период приобретения квартиры и форма собственности не влияют на активность собственников и их ответственное отношение. Таким образом, выводы О.С. Сидоровой о влиянии продолжительности проживания на активность собственников [Сидорова, 2013] не подтверждаются. 
Более трети опрошенных (34,7\%) стали собственниками квартиры в МКД посредством получения ипотечного кредита. Пятая часть респондентов $(19,3 \%)$ приобрели квартиру на заработанные, накопленные средства. Трети респондентам $(30,9 \%)$ квартира досталась по наследству или с покупкой квартиры помогли родственники. С одной стороны, прослеживается общероссийская тенденция: большинство граждан не могут позволить себе приобретение жилья самостоятельно без получения ипотечного кредита или помощи родственников, с другой - способ приобретения квартиры в МКД не влияет на активность участия собственников в ОС, равно как и наличие автомобиля и (или) иного недвижимого имущества в России или за рубежом.

Почти две трети собственников $(57,9 \%)$ имеют квартиру в типовом МКД серийной постройки в СССР, 26,1\% - в новостройке эконом-класса. Оставшиеся проценты распределились между собственниками квартир в новостройках комфорт-класса (13,8\%), бизнес-класса (1,3\%) и элитного жилья (0,9\%). Тип (качество) жилья также не влияет на участие собственников в ОС, что опровергает гипотезу О. С. Сидоровой о влиянии характеристик МКД на активность жителей в управлении домом [Сидорова, 2013].

Более половины собственников в совокупности хотели (26,7 \%) или скорее хотели (31,3\%) иметь квартиру в своем МКД-именно эти собственники чаще и активнее принимают участие в ОС (см. рис. 10), что свидетельствует об их осознанном ответственном отношении как к своей квартире, так и к общему имуществу МКД, в котором она находится. Намерение человека продать квартиру не влияет на активность его участия в ОС, несмотря на то что бо́льшая часть собственников (53,3\%) не планирует продавать квартиру в ближайшее время.

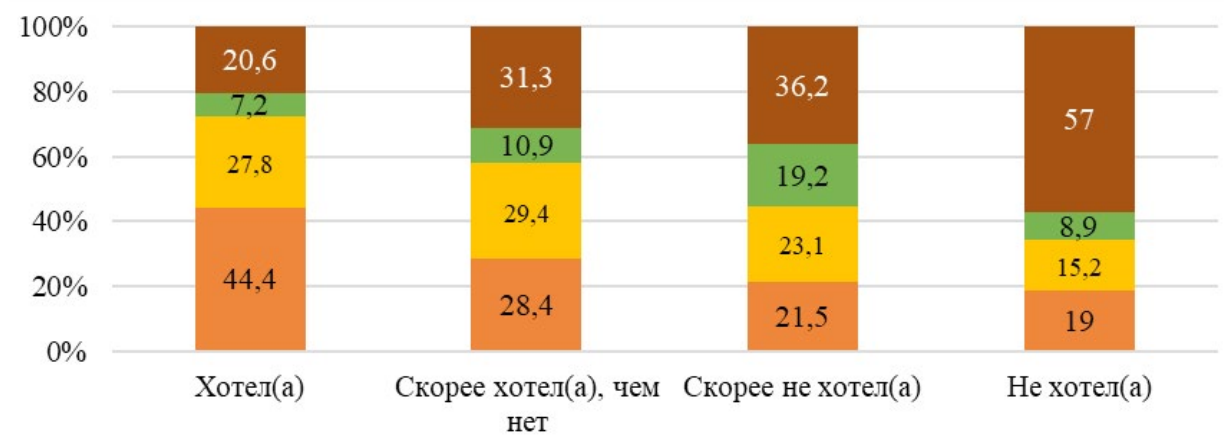

Принимают участие в каждом собрании $\square$ Принимают участие от случая к случаю
ॠрайне редко принимают участие $\quad$ Кникогда не принимают участие

Рис. 10. Дифференциация участия собственников в ОС по желанию иметь квартиру в конкретном МКД (\%)

В ходе исследования были выявлены различные формы отношения собственников к своей квартире в МКД (см. табл. 1). Практически половина собственников охарактеризовали свою квартиру как "домашний очаг, пространство уюта и ком- 
форта", а для пятой части всех респондентов квартира "просто удовлетворяет потребность в жилье". Тем не менее отношение собственника к своей квартире не влияет на его отношение к общему имуществу. Скорее всего, это связано с тем, что собственники по-прежнему отождествляют свое жилище именно с квартирой, а не с МКД, в котором она находится.

Таблица 1. Отношение респондентов к своей квартире в МКд

\begin{tabular}{|l|c|}
\hline \multicolumn{1}{|c|}{ Варианты ответа } & \% (от всего массива) \\
\hline Это домашний очаг, пространство уюта и комфорта & 44,9 \\
\hline Это мой капитал, потому что я работаю дома & 0,3 \\
\hline Квартира просто удовлетворяет мою потребность в жилье & 19,4 \\
\hline Это не более чем инвестиционная квартира & 2,1 \\
\hline Это семейная (родовая) квартира & 13,3 \\
\hline Квартира в первую очередь отражает мой социальный статус & 1,3 \\
\hline “Мой дом - моя крепость» & 10,7 \\
\hline Затрудняюсь ответить & 6,5 \\
\hline
\end{tabular}

Таким образом, период, в котором квартира была получена в собственность, и способ приобретения, тип (качество) МКД, а также форма собственности не влияют на активность участия собственников в ОС. Не влияет и отношение собственников к своему жилью, а также желание или нежелание продавать квартиру в ближайшее время, равно как и наличие иного движимого или недвижимого имущества. Влияет на участие в ОС тот факт, хотел ли собственник иметь квартиру в своем МКД.

\section{Заключение}

Удалось ли за 30 лет приватизации жилья воспитать ответственных собственников? Ответ на этот вопрос на сегодняшний день представляется очевидным. Подавляющее большинство собственников никогда не инициировали ОС и не выступали в роли председателя и секретаря собрания. Более трети собственников никогда не принимают участие в ОС, потому что не видят в этом никакого смысла и/или не находят на это времени. Более чем в половине МКД не избран совет дома. Собственники незнакомы с такими нормами жилищного законодательства, как орган управления МКД, состав общего имущества, компетенция ОС и право его инициирования.

Результаты исследования свидетельствуют о том, что реформа ЖКХ в России состоялась не до конца - уровень жилищной грамотности собственников достаточно низкий, они до конца не понимают свои жилищные права и обязанности, не осознают общее имущество как объект права и т. п. Таким образом, задачи "Стратегии развития жилищно-коммунального хозяйства в Российской Федерации на период до 2020 года" не были реализованы в полной мере, а ключевое направление по формированию ответственных собственников помещений в МКД, 
выражающееся в активном участии в ОС, не было должным образом обеспечено решением поставленных задач.

В ходе исследования были выявлены социально-демографические, социально-экономические, управленческие и иные факторы, влияющие на активность участия собственников помещений в МКД в ОС в России (см. табл. 2).

Таблица 2. Факторы активности собственников

\begin{tabular}{|c|c|c|}
\hline Группа факторов & Влияющие факторы & Не влияющие факторы \\
\hline Соседство & $\begin{array}{l}\text { Участие в общественных меро- } \\
\text { приятиях, знакомство с соседя- } \\
\text { ми, количество квартир в МКД }\end{array}$ & $\begin{array}{l}\text { Количество этажей, подъездов } \\
\text { в МКД }\end{array}$ \\
\hline $\begin{array}{l}\text { Социально-демографические } \\
\text { и экономические }\end{array}$ & Возраст, образование & $\begin{array}{l}\text { Пол, род деятельности, матери- } \\
\text { альное положение }\end{array}$ \\
\hline Жилищная грамотность & $\begin{array}{l}\text { Знание норм жилищного } \\
\text { законодательства (орган управ- } \\
\text { ления МКД, состав общего иму- } \\
\text { щества, право инициирования } \\
\text { ОС, компетенция ОС) }\end{array}$ & $\begin{array}{l}\text { Высшее образование не влия- } \\
\text { ет на знание норм жилищного } \\
\text { законодательства }\end{array}$ \\
\hline Управленческие факторы & $\begin{array}{l}\text { Наличие избранного совета } \\
\text { МКД и осведомленность } \\
\text { об этом жителей дома }\end{array}$ & $\begin{array}{l}\text { Качество обслуживания МКД, } \\
\text { способ управления }\end{array}$ \\
\hline Прочие факторы & $\begin{array}{l}\text { Желание собственника иметь } \\
\text { квартиру в конкретном МКД }\end{array}$ & $\begin{array}{l}\text { Период и способ приобретения } \\
\text { квартиры, форма собственно- } \\
\text { сти, тип (качество) жилья, жела- } \\
\text { ние или нежелание продавать } \\
\text { квартиру в ближайшее время, } \\
\text { форма отношения к квартире, } \\
\text { наличие автомобиля и/или } \\
\text { иного недвижимого имущества } \\
\text { в России или за рубежом }\end{array}$ \\
\hline
\end{tabular}

В результате анализа факторов, влияющих на активность собственников, можно сформировать профиль ответственного собственника в России: человек среднего или старшего возраста, имеющий высшее образование и в то же время неплохо знающий нормы жилищного законодательства. Образ МКД, в котором проживают ответственные собственники,- - дом с небольшим количеством квартир, в котором избран совет, и собственники об этом осведомлены, где живут хорошо друг друга знающие люди, изначально хотевшие иметь там квартиру и активно принимающие участие в различных общественных мероприятиях.

Проанализированный набор факторов не окончателен. Например, для будущих исследований представляет определенный интерес влияние экономического поведения (своевременность оплаты за жилищно-коммунальные услуги, наличие задолженности и т. п.), семейных отношений (наличие детей и домашних животных как фактор повышения ответственности; делегирование полномочий участвовать в ОС конкретному члену семьи и т. д.), вероисповедания (известно, что отношение 
к жилищу в мировых религиях разное), не просто размеров МКД, а конкретного этажа проживания (учитывая влияние высоты на психосоциальное самочувствие индивидов, логично предположить, что жители нижних этажей более активны, чем обитатели верхних) и др.

Ввиду того, что полученные статистические показатели и корреляции соотносятся с отдельными результатами исследований, проводившихся в других городах России в разные годы, можно говорить о репрезентативности сделанных выводов. Ситуация в Новосибирске вполне типична и может быть экстраполирована на другие города (в первую очередь мегаполисы) России.

По результатам исследования целесообразно внести ряд предложений по совершенствованию системы образования, жилищной политики и законодательства РФ:

1. Принимая во внимание тот факт, что наличие высшего образования не влияет на знание норм жилищного законодательства, от которого зависит участие собственников в ОС, было бы целесообразно усилить пропаганду жилищной грамотности, активизировать работу с собственниками помещений в МКД на всех уровнях, предусмотреть наличие предмета (дисциплины) по ЖКХ в программах высшего и среднего образования, либо ввести отдельные занятия по данной теме в рамках, например, дисциплины "Правоведение", "Безопасность жизнедеятельности".

2. Целесообразно активизировать работы по избранию советов МКД управляющими организациями и в первую очередь органами местного самоуправления. Логичным было бы введение обязательной регистрации совета МКД в органах местного самоуправления - на сегодняшний день администрации районов и городских округов попросту не владеют необходимой информацией для исполнения обязанностей по созыву ОС для избрания совета МКД и его председателя в домах, где совет не избран.

3. Ввиду того, что большую роль играют участие собственников в общественных мероприятиях и степень соседства, требуется дальнейшая поддержка работы территориальных общественных самоуправлений по вовлечению жителей в проведение дворовых праздников, участие в субботниках и т. п., где люди смогут познакомиться со своими соседями, что чрезвычайно важно для повышения активности участия собственников в ОС.

4. Положительный эффект возможен и от дальнейшего развития программ ипотечного кредитования и прочих жилищных программ, способствующих получению в собственность гражданами РФ квартир именно в тех МКД, в которых они хотели бы жить, что может сказаться на повышении уровня ответственности по отношению к общему имуществу в МКД.

5. Кажется логичным, с одной стороны, проведение оптимизации жилищного законодательства, с другой - пересмотр правовых норм в части размеров необходимого кворума для принятия тех или иных решений на ОС (уменьшение или отмена кворума в отдельных случаях). Альтернативой может служить пример учета голосов квартир, ни один из собственников которых не принял участие в голосовании за реновацию в Москве. До июня 2017 г. все голоса квартир, не принявших участие в голосовании, учитывались как голоса "за", с июня 2017 г. голоса не проголосовавших распределяются пропорционально голосам всех квартир, которые проголосовали «за" и «против" реновации. 
Реализация вышеуказанных предложений могла бы способствовать повышению эффективности проводимой в стране реформы ЖКХ, воспитанию ответственных и активных собственников, знающих свои права и обязанности. В конечном счете это отразилось бы на качестве жизни и на облике российских городов в целом.

\section{Список литературы (References)}

Абрамова Н.В. Вызовы и перспективы реформ ЖКХ и вовлечения собственников в управление жилищным фондом: социологический анализ // Мониторинг общественного мнения: экономические и социальные перемены. 2020. № 2. С. 65-83. https://doi.org/monitoring.2020.2.717.

Abramova N. V. (2020) Challenges and Prospects for Housing Reform and the Involvement of Owners in the Housing Stock Management: A Sociological Analysis. Monitoring of Public Opinion: Economic and Social Changes. No. 2. P. 65-83. https:// doi.org/monitoring.2020.2.717. (In Russ.)

Горшков М. К., Тихонова Н.Е., Андреев А. Л., Горюнова С. В. Собственность В жизни россиян: реальность и домыслы // Социологические исследования. 2005. № 11. C. 3-18. URL: http://ecsocman.hse.ru/socis/msg/18808737.html (дата обращения: 22.03.2021). (In Russ.)

Gorshkov M. K., Tikhonova N. E., Andreev A. L., Goryunova S. V. (2005) Property in Russians' Lives: Reality and Myths. Sociological Studies. No. 11. P. 3-18. URL: http:// ecsocman.hse.ru/socis/msg/18808737.html (accessed: 22.03.2021). (In Russ.)

Информационное общество в Российской Федерации. 2019: статистический сборник. М. : НИУ ВШЭ, 2019. https://rosstat.gov.ru/storage/mediabank/infoob2019_405737.pdf (дата обращения: 16.04.2021).

Information Society in the Russian Federation. 2019: Statistical Collection. (2019) Moscow: HSE University. https://rosstat.gov.ru/storage/mediabank/info-ob2019_ 405737.pdf (accessed: 16.04.2021). (In Russ.)

Ермишина А. В, Клименко Л.В. В поисках эффективных собственников в многоквартирном доме // Экономическая социология. 2010. Т. 11. № 4. С. 105-136. https://doi.org/10.17323/1726-3247-2010-4-105-136.

Ermishina A. V., Klimenko L. V. (2010) Searching Efficient Owners in the Apartment House. Journal of Economic Sociology. Vol. 11. No. 4. P. 105-136. https://doi.org/ 10.17323/1726-3247-2010-4-105-136. (In Russ.)

Литвинцев Д. Б. Формальные социальные институты в управлении многоквартирными домами в России: анализ протоколов общих собраний // Государственное и муниципальное управление. Ученые записки. 2020. Т. 1. № 2. С. 209-217. https://doi.org/10.22394/2079-1690-2020-1-2-209-217.

Litvintsev D. B. (2020) Formal Social Institutions in the Management of Condos in Russia: Analysis of Protocols of General Meetings. State and Municipal Management. Scholar Notes. Vol. 1. No. 2. P. 209-217. https://doi.org/10.22394/2079-16902020-1-2-209-217. (In Russ.) 
Волков Д., Колесников А. Новая русская мечта: частная собственность для детей // Московский Центр Карнеги. 2018. URL: https://carnegieendowment.org/ files/Kolesnikov_Volkov_Rus_web_final.pdf (дата обращения: 23.03.2021).

Volkov D., Kolesnikov A. (2018) New Russian Dream: Private Property for Children. Carnegie Moscow Center. URL: https://carnegieendowment.org/files/Kolesnikov_ Volkov_Rus_web_final.pdf (accessed: 23.03.2021). (In Russ.)

Осведомленность россиян о реформе ЖКХ, сентябрь 2019 г. / Всероссийский центр изучения общественного мнения (ВЦИОМ). URL: https://fondgkh.ru/workresult/infografika/social-studies/ (дата обращения: 8.04.2021).

Russian Public Opinion Research Center (VCIOM). Awareness of Russians About Housing and Communal Services Reform, September 2019. URL: https://fondgkh. ru/work-result/infografika/social-studies/ (accessed: 8.04.2021). (In Russ.)

Рыжова Н.П., Журавская Т.Н. Жилищный вопрос в советской и постсоветской России: трансформация отношений собственности и повседневная политика // Мир России. 2019. Т. 28. № 3. С. 48-66. https://doi.org/10.17323/1811-038X2019-28-3-48-66.

Ryzhova N. P., Zhuravskaya T. N. (2019) Housing in Soviet and Post-Soviet Russia: The Transformation of Property Relations and Everyday Resistance. Universe of Russia. Vol. 28. No. 3. P. 48-66. https://doi.org/10.17323/1811-038X-2019-28-3-48-66. (In Russ.)

Сидорова О.С. Управление многоквартирным домом: факторы и мотивы социальной активности // Мониторинг общественного мнения: экономические и социальные перемены. 2013. № 4. C. 150-159. URL: https://monitoringjournal.ru/index. php/monitoring/article/view/1535 (дата обращения: 23.03.2021).

Sidorova O.S. (2013) Management in Multi-Unit Apartment Building: Factors and Incentives for Social Activity. Monitoring of Public Opinion: Economic and Social Changes. No. 4. P. 150-159. URL: https://monitoringjournal.ru/index.php/monitoring/article/view/1535 (accessed: 23.03.2021). (InRuss.)

Borisova E. I., Polishchuk L., Peresetsky A. (2014) Collective Management of Residential Housing in Russia: The Importance of Being Social. Journal of Comparative Economics. Vol. 42. No. 3. P. 609-629. https://doi.org/10.1016/j.jce.2014.04.007.

Chu F.-N., Chang Ch.-Oh, Sing T. F. (2013) Collective Action Dilemmas in Condominium Management. Urban Studies. Vol. 50. No. 1. P. 128-147. https://doi.org/ 10.1177/0042098012452327.

Harris D. C. (2011) Condominium and the City: The Rise of Property in Vancouver. Law \& Social Inquiry. Vol. 36. No. 3. P. 694-726. https://doi.org/10.1111/j.17474469.2011.01247.x.

Lehavi A. (2015) Law, Collective Action and Culture: Condominium Governance in Comparative Perspective. Asia Pacific Law Review. Vol. 23. No. 2. P. 5-35. https:// doi.org/10.1080/10192557.2015.11745934. 
Litvintsev D. B., Osmuk L. A., Litvintseva G. P. Condos in Russia: Socio-Economic Aspect. In: Veber J., Guzikova L. (eds.) (2020) Proceedings of the New Silk Road: Business Cooperation and Prospective of Economic Development (NSRBCPED 2019). Series AEBMR. Vol. 131. France: Atlantis Press SARL. P. 206-212. https://doi.org/ aebmr.k.200324.039.

Patel Dh. (2017) The Evolution of Elite High-Rise Condominiums in India: From the Global to the Neo-Colonial? Postcolonial Studies. Vol. 20. No. 4. P. 456-478. https:// doi.org/10.1080/13688790.2017.1407281.

Preston V., Murdie R., Northrup D. (1993) Condominiums: An Investment Decision or Lifestyle Choice? A Comparative Study of Resident and Nonresident Condominium Owners in the City of Toronto. Netherlands Journal of Housing and the Built Environment. Vol. 8. No. 3. P. 281-300. https://doi.org/10.1007/bf02496600.

Yamazaki F., Sadayuki T. (2017) The Collective Action Problem in Japanese Condominium Reconstruction. International Real Estate Review. Vol. 20. No. 4. P. 493-523. URL: https://www.gssinst.org/irer/2020/04/27/the-collective-action-problemin-japanese-condominium-reconstruction/ (accessed: 23.03.2021). 


\section{Приложение}

Социально-демографические и экономические характеристики выборочной совокупности

\begin{tabular}{|l|c|}
\hline Район г. Новосибирска & \% (от всего массива) \\
\hline Ленинский & 21,8 \\
\hline Октябрьский & 15,7 \\
\hline Калининский & 11,9 \\
\hline Кировский & 13,2 \\
\hline Дзержинский & 9,3 \\
\hline Заельцовский & 7,6 \\
\hline Советский & 6,4 \\
\hline Первомайский & 4,7 \\
\hline Центральный & 4,1 \\
\hline Железнодорожный & 5,3 \\
\hline
\end{tabular}

\begin{tabular}{|c|c|}
\hline Пол & \% (от всего массива) \\
\hline Мужской & 34,4 \\
\hline Женский & 65,6 \\
\hline
\end{tabular}

\begin{tabular}{|c|c|}
\hline \multicolumn{1}{|c|}{ Возраст } & \% (от всего массива) \\
\hline От 18 до 35 лет & 57,6 \\
\hline От 36 до 60 лет & 37,2 \\
\hline 61 год или старше & 5,2 \\
\hline
\end{tabular}

\begin{tabular}{|l|c|}
\hline \multicolumn{1}{|c|}{ образование } & \% (от всего массива) \\
\hline Основное общее & 0,6 \\
\hline Среднее общее & 5 \\
\hline Среднее профессиональное & 19,9 \\
\hline Высшее (в т. ч. незаконченное) & 66,2 \\
\hline Два и более высших & 8,3 \\
\hline
\end{tabular}

\begin{tabular}{|l|c|}
\hline \multicolumn{1}{|c|}{ Род деятельности } & \% (от всего массива) \\
\hline Самозанятый (фрилансер) & 6,1 \\
\hline Индивидуальный предприниматель & 3,3 \\
\hline Руководитель или учредитель организации & 4,1 \\
\hline Наемный работник & 52,9 \\
\hline Государственный или муниципальный служащий & 14,5 \\
\hline Безработный (в т. ч. учащийся, пенсионер, домохозяйка) & 19,1 \\
\hline
\end{tabular}




\begin{tabular}{|l|c|}
\hline \multicolumn{1}{|c|}{ Материальное положение } & \% (от всего массива) \\
\hline $\begin{array}{l}\text { Мы едва сводим концы с концами. Денег не хватает даже } \\
\text { на продукты }\end{array}$ & 5,2 \\
\hline $\begin{array}{l}\text { На продукты денег хватает, но покупка одежды для нас } \\
\text { затруднительна }\end{array}$ & 18,8 \\
\hline $\begin{array}{l}\text { Денег хватает на продукты и одежду, но покупка холодильника, } \\
\text { телевизора, мебели для нас проблема }\end{array}$ & 40,3 \\
\hline $\begin{array}{l}\text { Мы можем без труда купить холодильник, телевизор, мебель, } \\
\text { но на большее денег нет }\end{array}$ & 26,5 \\
\hline $\begin{array}{l}\text { Мы можем позволить себе практически все: машину, } \\
\text { квартиру, дачу и многое другое }\end{array}$ & 2,2 \\
\hline Затрудняюсь ответить & 7 \\
\hline
\end{tabular}

\begin{tabular}{|l|c|}
\hline \multicolumn{1}{|c|}{ Собственность (множественный выбор) } & \% (от всего массива) \\
\hline Загородный дом или дача в России & 40,4 \\
\hline Еще одна или несколько квартир в России & 18,9 \\
\hline Один или несколько автомобилей & 74,4 \\
\hline Родовое (семейное) захоронение на общественном кладбище & 3,6 \\
\hline Недвижимость за рубежом & 1,4 \\
\hline
\end{tabular}

